\title{
Depolarized cell growth precedes filamentation during the process of ethanol- induced pseudohyphal formation in the yeast Candida tropicalis
}

\author{
Takahito Suzuki, ${ }^{1}$ Yumi Imanishi, ${ }^{1}$ Shin-Ichi Iwaguchi ${ }^{1}$ \\ and Teijiro Kamihara ${ }^{2} \dagger$ \\ Author for correspondence: Takahito Suzuki. Tel: +8174220 3419. Fax: +81742203419 \\ e-mail: takahito@cc.nara-wu.ac.jp
}

1 Department of Biological Science, Faculty of Science, Nara Women's University, Nara 630, Japan

2 Department of Material Chemistry, Faculty of Engineering, Kyoto University, Kyoto 606-1, Japan

\begin{abstract}
Ethanol has been reported to cause mycelial growth in Candida tropicalis Pk233, and mycelial growth has also been shown to be abolished by concomitant addition of myo-inositol. In this study, the process of ethanolinduced mycelial growth in this organism was examined in combination with cytological characterization of actin localization. Cultivation with ethanol gave biphasic growth curves. During the first growth phase (doubling time $2 \cdot 4 \mathrm{~h}$ ), there was an accumulation of swollen spherical yeast cells, instead of the oblong ones observed in the control culture, followed by the appearance of spherical daughter cells in chains. Randomly distributed actin patches were observed on these swollen yeast cells and the bud initiation sites of these cells appeared random. These observations suggested that ethanol caused depolarization of cell growth during the first phase. During the second growth phase (doubling time 7.4 h), pseudohyphal cells appeared, projecting from the swollen yeast cells. Activity of chitinase in the control culture rose during the exponential phase. In the ethanol culture the activity stayed at a low level throughout the growth phases. When pseudohyphal cells were transferred to fresh ethanol medium, yeast cells appeared from pseudohyphal filaments and changed their shape to spherical, and filamentation appeared to be inhibited during the first phase. From these observations, an initial effect of ethanol on c. tropicalis cells appeared to be depolarization of cell growth, and the resulting swollen cells grew as polar pseudohyphal cells. In the culture supplemented with both ethanol and inositol, or with both ethanol and sorbitol, the accumulation of swollen cells was not observed and single yeast cells with normal oblong shape were seen throughout the growth phases.
\end{abstract}

Keywords: Candida tropicalis, hyphal growth, ethanol, chitinase, actin localization

\section{INTRODUCTION}

Dimorphic transitions in fungi describe the ability of fungal cells to alternate between different growth patterns, especially to grow either as a yeast form or as a mycelial one. There has been great interest in fungal

\footnotetext{
† Present address: Osaka University of Health and Sport Sciences, Kumatori, Osaka 590-04, Japan.

Abbreviations: DAPI, 4', 6'-diamidino-2-phenylindole; $\mathrm{Rh}-\mathrm{Ph}$, rhodaminephalloidin.
}

dimorphism as a simple model of cellular morphogenesis (Harold, 1995).

The yeast-to-pseudohyphal transition seems to be coupled to the control of polarity in cell growth. When a bud has grown to two-thirds of its circumference, the apical growth zone shuts down and general growth completes bud expansion during yeast growth. In marked contrast, during pseudohyphal growth, the apical growth zone does not shut down as long as the daughter cell grows in the pseudohyphal form (Gimeno et al., 1992). Bud site assembly and yeast growth are 
coupled to reorganization of the actin cytoskelton; and the distribution of actin cytoskeleton changes through the cell cycle in Saccharomyces cerevisiae (Novick \& Botstein, 1985; Drubin, 1991; Evangelista et al., 1997), as well as in Candida albicans (Anderson \& Soll, 1986). Actin localization has been suggested to play a role in cell wall deposition and growth in both organisms. Especially, there is a strong correlation between occurrence of active growth at the bud tip and clustering of cortical actin patches in S. cerevisiae (Qadota et al., 1996). In terms of function, the actin cytoskelton has been implicated in maintenance of cell polarity, especially with respect to membrane growth and protein secretion, in changes in cell shape, in resistance to osmotic forces, and in response to environmental signals (Botstein et al., 1997).

The dimorphic transition from yeast to pseudohyphae in the petroleum-assimilating yeast Candida tropicalis occurs following the addition of ethanol (Tani et al., 1979; Yamada et al., 1982) but the addition of inositol prevents the ethanol-induced pseudomycelial formation (Tani et al., 1979; Omi \& Kamihara, 1989). This ethanol-induced dimorphic transition can be controlled in liquid cultures and seems to be a suitable system for physiological and cytological studies on individual cells during the process of dimorphic transition. In this study, actin distribution on individual cells during the process of ethanol-induced pseudohyphal development was examined, and chitinase activity in cell wall fractions of the cultures was monitored.

\section{METHODS}

Strains and culture conditions. The strain used in this study was Candida tropicalis $\mathrm{Pk} 233$. Yeast cells were precultured as colonies on YPD solid medium as described previously (Suzuki et al., 1991). Inocula were prepared by seeding a loopful of cells into $100 \mathrm{ml}$ synthetic medium ( $\mathrm{pH} 6.0)$ containing $\left(\mathrm{g} \mathrm{l}^{-1}\right)$ : $\mathrm{KH}_{2} \mathrm{PO}_{4}, 3.4 ; \mathrm{Na}_{2} \mathrm{HPO}_{4}, 3.9$; glucose, 20 ; vitamin-free Casamino acids (Difco), 5 ; $\left(\mathrm{NH}_{4}\right)_{2} \mathrm{SO}_{4}, 5 ; \mathrm{MgSO}_{4} .7 \mathrm{H}_{2} \mathrm{O}, 0 \cdot 125$; $\mathrm{FeCl}_{3} .6 \mathrm{H}_{2} \mathrm{O}, 0.025 ; \mathrm{KCl}, 0.425 ; \mathrm{CaCl}_{2} .2 \mathrm{H}_{2} \mathrm{O}, 0.125$; and biotin, $20 \times 10^{-6}$. Inoculated cultures were incubated at $30^{\circ} \mathrm{C}$ with shaking $(90$ r.p.m.) for approximately $30 \mathrm{~h}$. They were then diluted 200-fold into a fresh synthetic medium (control medium) and incubated at the same temperature (control culture). The ethanol medium was prepared by adding ethanol $\left(25 \mathrm{ml} \mathrm{l}^{-1}\right)$ to the control medium, and the ethanol-inositol medium by adding myo-inositol $\left(5 \mathrm{mg} \mathrm{l}^{-1}\right)$ to the ethanol medium. To examine the transition from hyphae to yeast, an ethanol culture which had been incubated for $48 \mathrm{~h}$ was diluted 100 -fold into fresh medium (control medium or ethanol medium). At various times during incubation, $5-10 \mathrm{ml}$ portions of each culture were taken for measuring chitinase activity and for fixation by adding an equal volume of $6 \%$ $(\mathrm{w} / \mathrm{v})$ formaldehyde solution in $0 \cdot 2 \mathrm{M}$ potassium phosphate buffer $(\mathrm{pH} 6 \cdot 5)$. The fixed sample was used for monitoring growth by measuring turbidity at $660 \mathrm{~nm}$ and for the observation of cell shape by phase-contrast microscopy.

Measurement of chitinase activity. Chitinase activity was measured in cell wall fractions of the cultures, according to the method described by Kuranda \& Robbins (1991). Samples of culture fluid containing approximately $2 \times 10^{8}$ cells were centrifuged at 3000 r.p.m. for $5 \mathrm{~min}$ at $4{ }^{\circ} \mathrm{C}$. Harvested cells were suspended in $200 \mu \mathrm{l}$ solution $\mathrm{A}$, consisting of $0.8 \% \mathrm{NaCl}$, $0.02 \% \mathrm{KCl}, 0.12 \% \mathrm{Na}_{2} \mathrm{HPO}_{4}, 0.02 \% \mathrm{KH}_{2} \mathrm{PO}_{4}$ and $0.1 \%$ Triton X-100. Acid-washed quartz sand was added to a level approximately $2 \mathrm{~mm}$ below the meniscus. The suspension was vortexed at maximum speed for $30 \mathrm{~s}$ at $4{ }^{\circ} \mathrm{C}$. The tube was placed on ice for 1-2 min. This procedure was repeated four times. The supernatant was recovered with a pipette and the residue washed twice with $0.5 \mathrm{ml}$ solution $A$. The supernatants were pooled and pelleted by centrifugation at 16000 r.p.m. for $1 \mathrm{~min}$. The cell wall pellet was then washed twice with $1 \mathrm{ml}$ solution A by centrifugation, and finally suspended in $200 \mu \mathrm{l}$ $0.1 \mathrm{M}$ sodium citrate buffer, $\mathrm{pH} 3 \cdot 0$. Portions $(20 \mu \mathrm{l})$ of cell wall suspensions were mixed with $80 \mu \mathrm{l} 250 \mu \mathrm{M}$ 4-methylumbelliferyl $\beta$-D- $N, N^{\prime}, N^{\prime \prime}$-triacetylchitotrioside in $0 \cdot 1 \mathrm{M}$ sodium citrate buffer $(\mathrm{pH} 3 \cdot 0)$, and incubated at $30^{\circ} \mathrm{C}$ for $1 \mathrm{~h}$. The reaction was stopped by adding $2.9 \mathrm{ml} 0.5 \mathrm{M}$ glycine/ $\mathrm{NaOH}$ buffer $(\mathrm{pH} \mathrm{10} \cdot 4)$. Debris was removed by centrifugation at 15000 r.p.m. for 5 min. The liberated 4-methylumbelliferone (4MU) was measured with a Hitachi F-2000 spectrophotofluorometer (excitation at $350 \mathrm{~nm}$, emission at $440 \mathrm{~nm}$ ). The calibration curve was calculated by fluorescence of standard concentrations of $4 \mathrm{MU}$ and chitinase activity was defined as nmol $4 \mathrm{MU}$ released $\mathrm{min}^{-1}$.

Fluorescence microscopy. To obtain well-fixed specimens for observing actin filaments, the microwave fixation method (Mizuhira et al., 1994) was used. Culture media were transferred into a test tube, and mixed with an equal volume of cold $0.2 \mathrm{M}$ potassium buffer $(\mathrm{pH} 6.5)$ containing $6 \%(\mathrm{w} / \mathrm{v})$ formaldehyde and $6 \%(\mathrm{w} / \mathrm{v})$ DMSO. The test tube was immediately floated on ice-water, exposed to microwaves for $30 \mathrm{~s}$ using a Hitachi electronic oven $(500 \mathrm{~W})$, and then incubated for $20 \mathrm{~min}$ at $37^{\circ} \mathrm{C}$. Fixed specimens were washed three times with PBS $(10 \mathrm{mM}$ phosphate buffer, $\mathrm{pH} 6.9$, containing $137 \mathrm{~m} \mathrm{M} \mathrm{NaCl}$ and $2.7 \mathrm{mM} \mathrm{KCl}$ ) by centrifugation $(3000 \mathrm{~g}$ for $5 \mathrm{~s})$. The cells were stained with rhodaminephalloidin ( $\mathrm{Rh}$ - $\mathrm{Ph}$; Molecular Probes) which had been diluted $1: 20$ in PBS, at $25^{\circ} \mathrm{C}$ for $3-4 \mathrm{~h}$. For double-staining, the cells were stained for $3-4 \mathrm{~h}$ with $\mathrm{Rh}-\mathrm{Ph}$ solution $(1: 20$ in PBS) containing either Calcofluor White at $0.5 \mathrm{mg}^{-1}$ or $4^{\prime}, 6^{\prime}$ diamidino-2-phenylindole (DAPI) at $0.5 \mathrm{mg} \mathrm{l}^{-1}$. Stained samples were examined with an epifluorescence microscope equipped with a phase-contrast apparatus (BH-2-RFL; Olympus).

\section{RESULTS}

\section{Biphasic growth of C. tropicalis Pk233 in the ethanol culture}

To clarify the events leading up to the formation of pseudohyphae, cell morphology was examined at various times in ethanol cultures and control cultures. At zero time, when $2.5 \%$ ethanol was added and the total count of inoculated cells was $2 \times 10^{6} \mathrm{ml}^{-1}$, unbudded cells accounted for $90 \%$ of the cell population, since the inoculum was from a stationary-phase culture. After $2 \mathrm{~h}$ incubation, the control culture entered the exponential phase. However, in the case of the ethanol culture, the lag phase lasted 3-4 h (Fig. 1a). Whereas the control culture showed apparently monophasic growth, the ethanol culture showed biphasic growth, changing when the $\mathrm{OD}_{600}$ of the culture reached around $1 \cdot 0$, at $12-15 \mathrm{~h}$ after inoculation (Fig. 1a). The doubling time in the midexponential phase was $1.8 \mathrm{~h}$ in the control culture. In the 


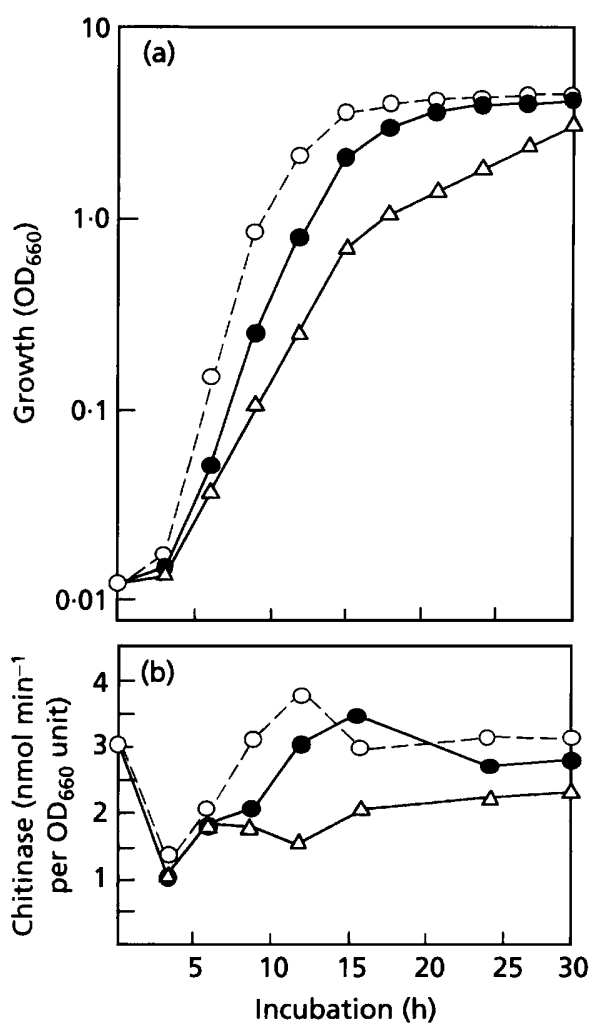

Fig. 1. Growth curve (a) and chitinase activity (b) of C. tropicalis Pk233 grown in control medium $(O)$, ethanol medium $(\triangle)$ or ethanol-inositol medium (O).

ethanol culture, doubling time was $2.4 \mathrm{~h}$ during the first phase and $7.4 \mathrm{~h}$ during the second phase.

The control culture did not show any significant presence of pseudohyphal cells throughout its growth cycle (Fig. 2a, b). Pseudohyphal cells appeared in the ethanol culture at $16-20 \mathrm{~h}$, when the culture entered into the second phase (Fig. 2e). As Tani et al. (1979) had described, the production of pseudohyphal cells depended on the continuous presence of the ethanol. During the first growth phase, individual yeast cells appeared to alter their shape from ellipsoidal to spherical (Fig. 2b, c). New-born daughter buds from spherical mother cells swelled isodiametrically. Until a late stage of the first phase of growth in the ethanol culture (12-15 h), several spherical yeast cells formed a chain, and small filamentous daughter buds appeared from the cells (Fig. 2d). Each cell of the chain increased in volume until the end of the first growth phase. These features were quite different from those of ellipsoidal yeast cells in the control culture, which were separated from each other (Fig. 2a, b). Until the inflection period of the ethanol culture, three to four spherical cells were in chains. After the culture entered the second phase of growth curve, polar elongated daughter cells grew from chained cells, and became pseudohyphae (Fig. 2d, e). Some of the chained cells changed their shape from spherical to spatulate or pyriform and produced a pseudohyphal cell at their tips (Fig. 2e). Until $30 \mathrm{~h}$ of incubation in the ethanol culture, many of the swollen cells produced more than two daughter pseudohyphal cells and each of the pseudohyphal ones had two or three septa (Fig. 2e).

\section{Cytological characterization of ethanol-induced pseudohyphal formation}

To clarify the morphological events occurring prior to the production of pseudohyphal cells, especially on the chained spherical cells, individual cells were examined for their distribution pattern of actin patches, because the pattern should reflect polarity of cell growth, as has been shown in a related species, C. albicans (Anderson \& Soll, 1986; Yokoyama et al., 1990; Akashi et al., 1994). The cells of the control culture were classified into six types according to their pattern of actin localization: type A was characterized by edge granules in a pre-evaginated cell (Fig. 3a), type B by clustered granules in a pre-evaginated cell (Fig. $3 \mathrm{~b}$ ), type $\mathrm{C}$ by generally distributed granules in a small bud (Fig. 3c), type $D$ by edge granules in bud (Fig. 3d), type $E$ by an apical cluster in an elongated bud (Fig. 3e), and type F by the presence of large neck granules on a septum (Fig. 3f). Budding sites of cells of the control culture were limited to the cell poles. At $15 \mathrm{~h}$ after ethanol addition, just before growth shifted to the second phase, formation of chains consisting of three to five yeast spheres occurred in the ethanol culture (Fig. 2c, Fig. 3g, h). Rh-Ph-stained cells at this period of the culture showed spherical swollen cells with edge actin granules (Fig. 3g-i). Small buds of the swollen cells had clustered granules. These swollen cells in a chain were counted as one chain and classified into three types according to the number of cells. If the size of a bud in a chain was at least twothirds the size of the mother cell of type $F$ in the control culture, the bud was regarded as mature and counted as one cell, since DAPI staining of such a bud showed a nucleus. Actin patches of such a mature bud were generally distributed. No elongated bud was detected until the culture entered the second growth phase. Locations of daughter-budding sites on these swollen cells appeared to be random (Fig. $3 \mathrm{~g}-\mathrm{i}$ ), compared to the sites of those of the control culture, which were limited to a cell pole (Fig. 3c-f). These observations supported the notion that the spherical yeast cells which appeared during the first phase of growth in the ethanol culture displayed depolarized cell growth. After entering the second phase of growth in the ethanol culture, the location of new-born daughter cells was limited to the tips of pyriform mother cells. Some of the spherical mother cells produced several pseudohyphal cells (Fig. $2 \mathrm{e})$, indicating that they remained depolarized.

To examine cell development in the first growth phase, the percentage of each type cell was examined at a given time in the cell population. Experiments were repeated three times; results from a representative one are shown in Table 1. At the start of the culture, the cell population consisted mainly of type A cells. The frequency of type 

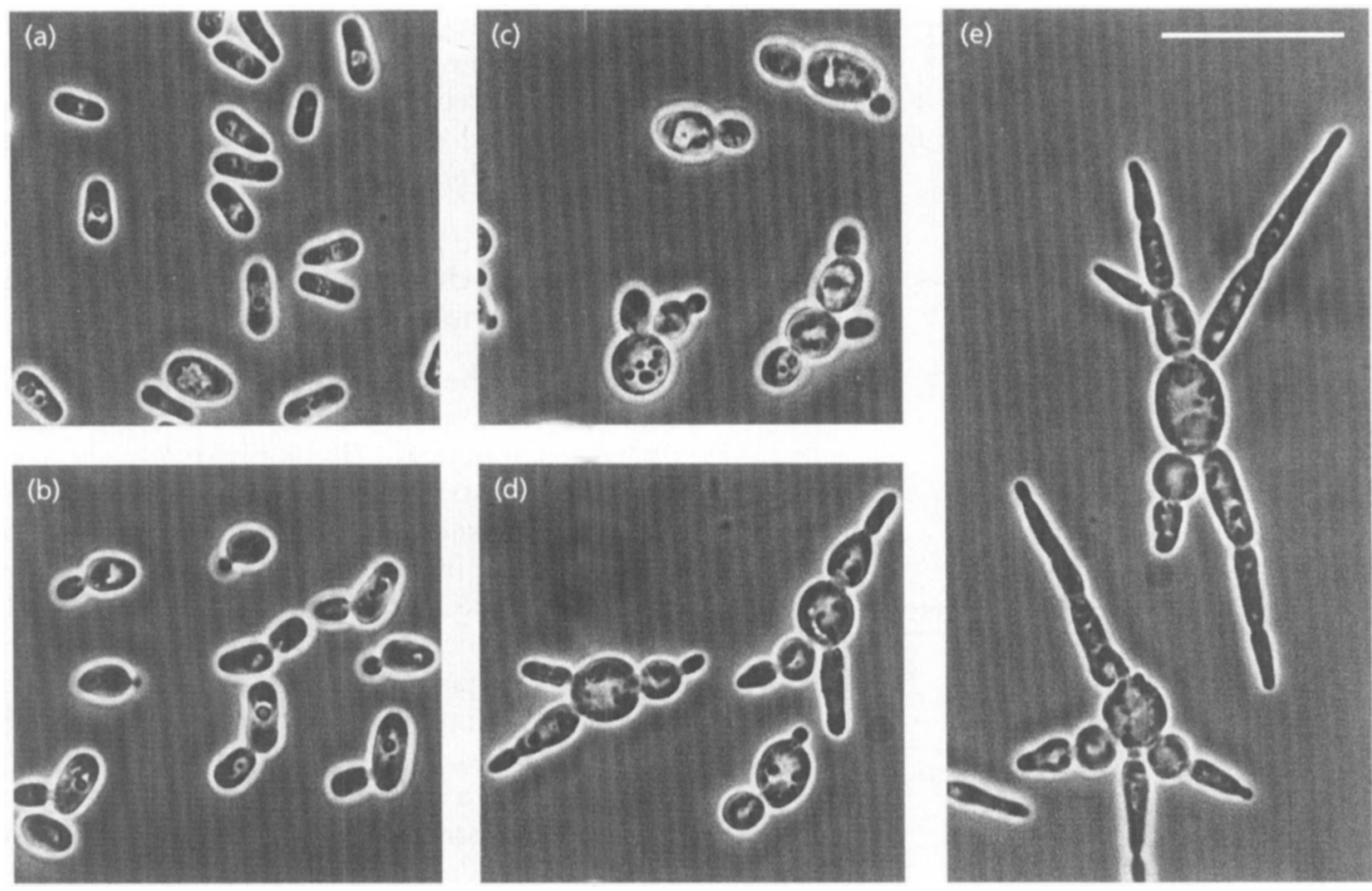

Fig. 2. Phase-contrast micrographs of $C$. tropicalis $P k 233$ cells grown in control culture at zero time (a) and at midexponential phase (b); or in the ethanol culture at the middle (c) and the late stage (d) of the first phase and the early stage (e) of the second phase. Bar, $30 \mu \mathrm{m}$.

B-F cells increased up to the mid-exponential phase. On the other hand, the population of the ethanol culture at the early stage of the first growth phase $(7 \mathrm{~h})$ showed about $60 \%$ type $\mathrm{C}$ and $\mathrm{D}$ cells, each having a daughter bud without elongation. At the middle stage of the first growth phase $(11 \mathrm{~h}), 80 \%$ of the population were swollen yeast cells, suggesting that individual cells of ethanol culture transformed their shape to a swollen one. At the later stage of the first growth phase $(15 \mathrm{~h})$, chains of three swollen cells occupied $40 \%$ of the population.

These observations suggested that the depolarized yeast cells in a chain, which were produced in the ethanol culture during the first growth phase, recovered their polarization during the second growth phase and produced daughter buds with polar growth. It should be noted that the degree of polarization of new daughter cell-growth at this period was rather higher than that of the control culture.

Budding of yeast cells was observed when filamentous cells of the ethanol culture were transferred to fresh control medium by 100 -fold dilution of a $48 \mathrm{~h}$ ethanol culture (Fig. $4 \mathrm{a}, \mathrm{b}$ ). On the other hand, after the ethanolinduced filamentous cells were similarly transferred to a fresh ethanol medium, the filamentous cells produced spherical daughter cells with depolarized growth (Fig. $4 c)$. This agrees with the idea that the first event in the ethanol culture was depolarization of cell growth rather than filamentous polar growth. Prolonged incubation of each of the transferred cultures gave mostly yeast cells in the control medium and chains of spherical yeast cells in the ethanol medium (Fig. 4d, e).

\section{Prevention of ethanol-induced pseudohyphal formation by addition of myo-inositol or sorbitol}

Addition of myo-inositol $(0.03 \mathrm{mM})$ to the ethanol culture medium (ethanol-inositol culture) prevented pseudohyphal formation, as observed by Tani et al. (1979). This culture showed monophasic growth with a doubling time at mid-exponential phase of $1.8 \mathrm{~h}$ (Fig. 1a). In this culture, the transient appearance of yeast cells in chains was observed at mid-exponential phase; the majority of these cells were ovate to oblong. The pattern of actin localization of these ovate to oblong cells was apparently similar to that in the control culture (not shown). Further incubation of the ethanol-inositol culture to late-exponential phase showed single yeast cells with an ovate to oblong shape occupying more than $98 \%$ of the cell population, and no significant formation of pseudohyphae was observed. Addition of $1 \mathrm{M}$ sorbitol to the ethanol culture also prevented pseudomycelial formation. The addition of $1 \mathrm{M}$ sorbitol to the yeast cultures gave a prolonged lag phase: $3 \mathrm{~h}$ in the control culture or $4 \mathrm{~h}$ in the ethanol culture. However, the doubling time in the mid-exponential phase was $1.8 \mathrm{~h}$ for the control culture and $2.2 \mathrm{~h}$ for the ethanol culture. The addition of $1 \mathrm{M}$ sorbitol to the ethanol culture prevented both growth inhibition and pseudo- 

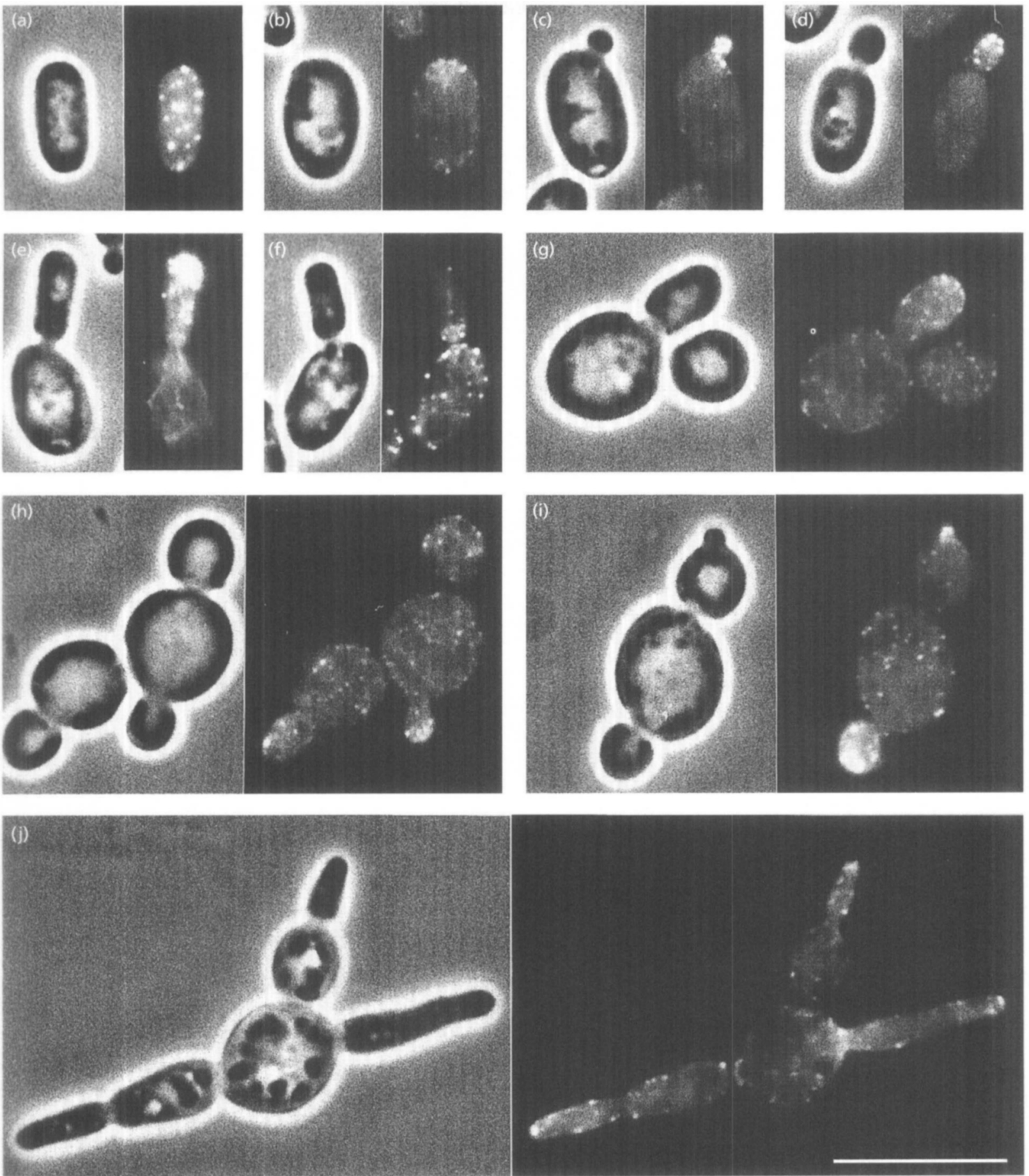

Fig. 3. Fluorescence and phase-contrast micrographs of $C$. tropicalis Pk233 cells stained with Rh-Ph showing the distribution of actin in the control culture $(a-f)$, or in the ethanol culture at the middle stage ( $g-i)$ of the first phase and the early stage (j) of the second phase. Bar, $30 \mu \mathrm{m}$.

mycelial formation by ethanol. The transient appearance of yeast cells in chains was also observed at the mid-exponential phase in the ethanol culture containing $1 \mathrm{M}$ sorbitol, but further incubation of the culture produced single yeast cells. No spherical cells appeared during growth in the presence of $1 \mathrm{M}$ sorbitol.

\section{Dimorphic transition and chitinase activity}

In the ethanol culture, daughter-cell separation appeared to be blocked and cells were in chains. Chitinase activity was examined in cell wall fractions of cells in the three cultures. From the control culture, chitinase activity 
Table 1. Percentage of cell types, classified according to the distribution pattern of actin patches, in various cultures

\begin{tabular}{|c|c|c|c|c|c|c|c|c|c|}
\hline \multirow{3}{*}{$\begin{array}{l}\text { Culture } \\
\text { (total cells) }\end{array}$} & \multicolumn{9}{|c|}{ Cell type: } \\
\hline & \multirow[b]{2}{*}{$\mathbf{A}$} & \multirow[b]{2}{*}{ B } & \multirow[b]{2}{*}{$\mathrm{C}$} & \multirow[b]{2}{*}{ D } & \multirow[b]{2}{*}{$\mathbf{E}$} & \multirow[b]{2}{*}{$\mathrm{F}$} & \multicolumn{3}{|c|}{ Swollen* } \\
\hline & & & & & & & 1 cell & 2 cells & 3 cells \\
\hline $\begin{array}{l}\text { Start }[0 \mathrm{~h}] \\
\quad(n=520)\end{array}$ & 88 & $1 \cdot 7$ & $4 \cdot 2$ & $2 \cdot 1$ & $3 \cdot 7$ & 0 & 0 & 0 & 0 \\
\hline $\begin{array}{l}\text { Control }[15 \mathrm{~h}] \\
(n=491)\end{array}$ & 32 & 9 & 17 & 14 & 19 & 9 & 0 & 0 & 0 \\
\hline $\begin{array}{l}\text { Ethanol }[7 \mathrm{~h}] \\
(n=229)\end{array}$ & 14 & 23 & 24 & 33 & 1 & 4 & 1 & 0 & 0 \\
\hline $\begin{array}{l}\text { Ethanol }[11 \mathrm{~h}] \\
(n=154)\end{array}$ & 0 & 1 & 1 & 8 & 0 & 0 & 28 & 53 & 9 \\
\hline $\begin{array}{l}\text { Ethanol }[15 \mathrm{~h}] \\
(n=189)\end{array}$ & 0 & 0 & 1 & 0 & 0 & 0 & 23 & 34 & 42 \\
\hline $\begin{array}{l}\text { Et-Ino* }[8 \mathrm{~h}] \\
(n=128)\end{array}$ & 5 & 9 & 32 & 16 & 10 & 28 & 0 & 0 & 0 \\
\hline $\begin{array}{l}\text { Et-Ino* }[12 \mathrm{~h}] \\
(n=257)\end{array}$ & 23 & 16 & 23 & 11 & 18 & 9 & 0 & 0 & 0 \\
\hline
\end{tabular}

Ethanol-inositol culture.

decreased during the early exponential phase and then increased until it reached the original level (Fig. 1b). This seemed to parallel the alteration of growth phase, from late-exponential to stationary (Fig. 1a). However, in the ethanol culture, chitinase activity was at a low level during the first phase of growth, in parallel with the chain formation of cells (Fig. 1b, Fig. 3g-i). Addition of myo-inositol to the ethanol culture resulted in an increase in chitinase activity, but the increase occurred a few hours later than in the control culture.

\section{DISCUSSION}

Inhibition of daughter-cell separation followed the depolarization in the ethanol culture. The appearance of the chains of yeast cells paralleled low levels of chitinase activity. The pseudohyphal cells that grew from these spherical yeasts did not separate from each other. Chitinase activity has been shown to be required for daughter cell separation in the normal cell cycle of $S$. cerevisiae (Cabib et al., 1992; Kuranda \& Robbins, 1991). The process of yeast-to-pseudomycelial transition in C. tropicalis seems to require low levels of chitinase activity.

In the presence of ethanol, addition of $0.03 \mathrm{mM}$ myoinositol or $1 \mathrm{M}$ sorbitol restored the chitinase activity to the control level and prevented the formation of both depolarized spherical cells in chains and polarized filamentous growth. The addition of ethanol is associated with a decrease in the molar ratio of the saturated acid content of phospholipids, especially of palmitic acid in phosphatidylinositol (Uejima et al., 1987; K.
Kono \& T. Kamihara, unpublished). However, in the presence of ethanol, addition of $0.03 \mathrm{mM}$ inositol prevented the decrease in the molar ratio of saturated acid content (K. Kono \& T. Kamihara, unpublished). Indirect evidence for inositol-phospholipid-linked signal transduction during filamentation has been obtained for this organism (Kamihara \& Omi, 1989), as well as for Fusarium graminearum (Prior et al., 1993). During the dimorphic transition from yeast cells to germ tubes in $C$. albicans, a sustained increase in cellular inositol trisphosphate levels was also reported to occur (Gadd \& Foster, 1997). The role in the dimorphic transition of phosphatidylinositol metabolism and a signal transduction pathway linked to it requires further investigation.

The morphogenetic pathway for development of pseudohyphae in C. tropicalis may consist of two steps: an inhibition of daughter-cell separation and formation of filamentous cells. These two steps also apply in the case of filamentous growth of $S$. cerevisiae on solid medium (Gimeno et al., 1992), but differ from the case of germ tube formation in C. albicans (Anderson \& Soll, 1986; Gow \& Gooday, 1987). Germ tubes represent the initiation of hyphal growth directly from yeast cells, have parallel walls at their point of origin, and are not constricted at septa (McGinnis, 1980). However, filamentous growth in nitrogen-limited $S$. cerevisiae and that in ethanol-induced C. tropicalis consists of a series of elongated yeast cells remaining attached, and their walls typically contain marked constrictions at the septa. In S. cerevisae, some diploid strains switch from budding cells to pseudohyphae under conditions of nitrogen starvation on solid medium (Gimeno et al., 1992; 

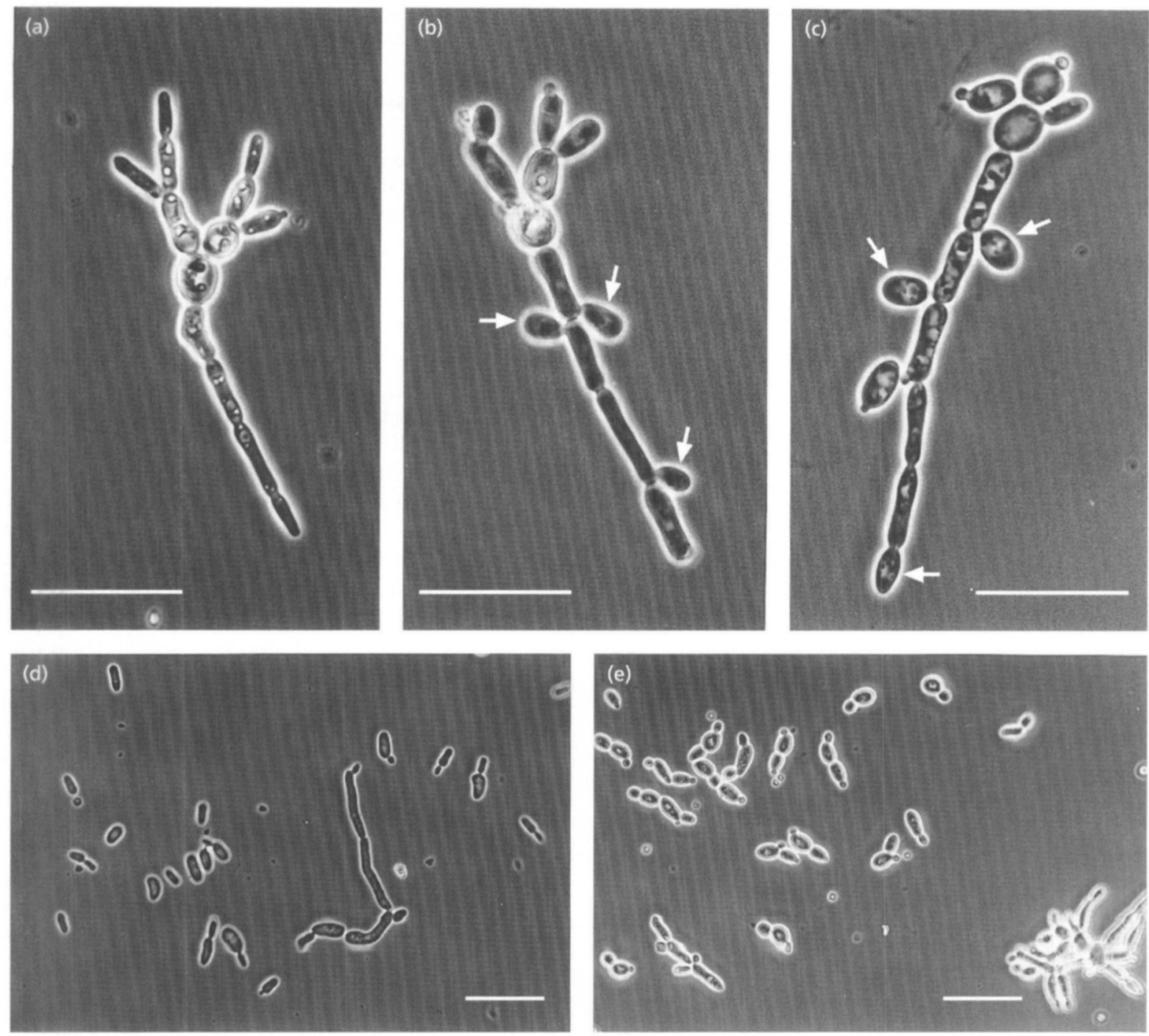

Fig. 4. Phase-contrast micrographs of $C$. tropicalis $P k 233$ cells grown in ethanol medium for $48 \mathrm{~h}$ (a) and then transferred to control conditions for $9 \mathrm{~h}$ (b) and $12 \mathrm{~h}$ (c), or to ethanol medium for $9 \mathrm{~h}$ (d) and $12 \mathrm{~h}(\mathrm{e})$. Newly formed yeast cells are shown by arrows. Bars, $30 \mu \mathrm{m}$.

Gimeno \& Fink, 1994). Elements of the yeast mating signal transduction pathway including the mitogenactivated protein (MAP) kinase cascade, are required for pseudohyphal growth (Liu et al., 1993; Madhani \& Fink, 1997). The same signalling kinase cascade that activates Ste12p in S. cerevisiae may also work in the filamentous growth of C. albicans (Liu et al., 1993; Gavrias et al., 1996). In the case of the dimorphic transition in C. tropicalis, elements of signal transduction pathways may work under ethanol induction. Identifications of specific genes for the process of ethanol-induced filamentation are in progress.

\section{ACKNOWLEDGEMENTS}

This work was supported in part by a grant in aid (no. 08640846) for scientific research from the Ministry of Education, Science, Sports and Culture of Japan.

\section{REFERENCES}

Akashi, T., Kanbe, T. \& Tanaka, K. (1994). The role of the cytoskeleton in the polarized growth of the germ tube in Candida albicans. Microbiology 140, 271-280.

Anderson, J. M. \& Soll, D. R. (1986). Differences in actin localization during bud and hypha formation in the yeast Candida albicans. J Gen Microbiol 132, 2035-2047.

Botstein, D., Amberg, D., Mulholland, J., Huffaker, T., Adams, A., Drubin, D. \& Stearns, T. (1997). The yeast cytoskeleton. In The Molecular and Cellular Biology of the Yeast Saccharomyces: Cell Cycle and Cell Biology, pp. 1-90. Edited by J. R. Pringle, J. R. Broach \& E. W. Jones. Cold Spring Harbor, NY: Cold Spring Harbor Laboratory.

Cabib, E., Silverman, S. J. \& Shaw, J. A. (1992). Chitinase and chitin synthase 1 : counterbalancing activities in cell separation of Saccharomyces cerevisiae. J Gen Microbiol 138, 97-102.

Drubin, D. G. (1991). Development of cell polarity in budding yeast. Cell 65, 1093-1096. 
Evangelista, M., Blundell, K., Longtine, M. S., Chow, C. J., Adames, N., Pringle, J. R., Matthias, P. \& Boone, C. (1997). Bni1p, a yeast formin linking $\mathrm{Cdc} 42 \mathrm{p}$ and the actin cytoskeleton during polarized morphogenesis. Science 276, 118-122.

Gadd, G. M. \& Foster, S. A. (1997). Metabolism of inositol 1,4,5trisphosphate in Candida albicans: significance as a precursor of inositol polyphosphates and in signal transduction during the dimorphic transition from yeast cells to germ tubes. Microbiology 143, 437-448.

Gavrias, V., Andrianopoulos, A., Gimeno, C. J. \& Timberlake, W. E. (1996). Saccharomyces cerevisiae TEC1 is required for pseudohyphal growth. Mol Microbiol 19, 1255-1263.

Gimeno, C. J. \& Fink, G. R. (1994). Induction of pseudohyphal growth by overexpression of PHD1, a Saccharomyces gene related to transcriptional regulators of fungal development. Mol Cell Biol 14, 2100-2112.

Gimeno, C., Ljungdahl, P. O., Styles, C. A. \& Fink, G. R. (1992). Unipolar cell divisions in the yeast $S$. cerevisiae lead to filamentous growth: regulation by starvation and RAS. Cell 68, 1077-1090.

Gow, N. A. \& Gooday, G.W. (1987). Cytological aspects of dimorphism in Candida albicans. Crit Rev Microbiol 15, 73-78.

Harold, F. M. (1995). From morphogenes to morphogenesis. Microbiology 141, 2765-2778.

Kamihara, T. \& Omi, K. (1989). Increase in cyclic AMP content with enhanced phosphatidylinositol turnover in the cells of Candida tropicalis during mycelial growth caused by ethanol. Yeast 5 (suppl.), 437.

Kuranda, M. J. \& Robbins, P. W. (1991). Chitinase is required for cell separation during growth of Saccharomyces cerevisiae. J Biol Chem 266, 19758-19767.

Liu, H., Styles, C. A. \& Fink, G. R. (1993). Elements of the yeast pheromone response pathway required for filamentous growth of diploids. Science 262, 1741-1744.

McGinnis, M. R. (1980). Laboratory Handbook of Medical Mycology. New York: Academic Press.

Madhani, H. D. \& Fink, G. R. (1997). Combinatorial control required for the specificity of yeast MARK signaling. Science 275, 1314-1317.
Mizuhira, V., Hasegawa, H. \& Notoya, M. (1994). Microwave fixation and localization of calcium in synaptic vesicles. $J$ Neurosci Methods 55, 125-136.

Novick, P. \& Botstein, D. (1985). Phenotypic analysis of temperature-sensitive yeast actin mutants. Cell 40, 405-416.

Omi, K. \& Kamihara, T. (1989). Accumulation of cAMP in the cells of Candida tropicalis at an early stage of ethanol-induced filamentous growth and its prevention by myo-inositol. Biochem Biophys Res Commun 162, 646-650.

Prior, S. L., Cuncliffe, B. W., Robson, G. D. \& Trinci, A. P. (1993). Multiple isomers of phosphatidyl inositol monophosphate and inositol bis- and trisphosphate from filamentous fungi. FEMS Microbiol Lett 110, 147-152.

Qadota, H., Python, C. P., Inoue, S. B., Arisawa, M., Anraku, Y., Zhen, Y., Watanabe, T., Levin, D. E. \& Ohya, Y. (1996). Identification of yeast Rho 1p GTPase as a regulatory subunit of 1,3beta-glucan synthase. Science 272, 279-281.

Suzuki, T., Miyamae, Y. \& Ishida, I. (1991). Variation of colony morphology and chromosomal rearrangement in Candida tropicalis pK233. J Gen Microbiol 137, 161-167.

Tani , Y., Yamada, Y. \& Kamihara, T. (1979). Morphological changes in Candida tropicalis pK233 caused by ethanol and its prevention by myo-inositol. Biochem Biophys Res Commun 91, 351-355.

Uejima, Y., Koga, T. \& Kamihara, T. (1987). Enhanced metabolism of phosphatidylinositol in Candida tropicalis in association with filamentous growth caused by ethanol. FEBS Lett 214, 127-129.

Yamada, Y., Tani, Y. \& Kamihara, T. (1982). Dimorphism in Candida tropicalis $\mathrm{Pk} 233$ in defined hydrocarbon media. Trans Mycol Soc Jpn 23, 137-142.

Yokoyama, K., Kaji, H., Nishimura, K. \& Miyaji, M. (1990). The role of microfilaments and microtubules in apical growth and dimorphism of Candida albicans. J Gen Microbiol 136, 1067-1075.

Received 15 July 1997; revised 3 October 1997; accepted 8 October 1997. 